\title{
Perbandingan Validitas Sistem Skoring Apache II, SOFA, Dan Customized Sequential Organ Failure Assessment (Csofa) Untuk Memperkirakan Mortalitas Pasien Non-Bedah Yang Dirawat Di Ruang Perawatan Intensif
}

Comparison Of Validity Apache II, SOFA And Customized Sequential Organ Failure Assessment (Csofa) For Predicting Non-Surgical Patient

Stefanus Taofik ${ }^{\bowtie *}$, Tjokorda Gde Agung Senapathi*, Made Wiryana*

*Bagian / SMF Ilmu Anestesi dan Terapi Intensif Fakultas Kedokteran Universitas Udayana / Rumah Sakit Umum Pusat Sanglah, Denpasar

$\bowtie$ Korespondensi/correspondence : Stefanus Taofik

\begin{abstract}
Background : Application of Sistem Jaminan Kesehatan Nasional (SJKN) in intensive care unit (ICU) service encourages ICU services for being more effective and efficient. Prediction of mortality is important either for administration or clinical in ICU management. Even non-surgical patient population is not large, but it has high mortality rate.
\end{abstract}

Objective : To gain good and easy to used scoring system, we assessed missing value, and discrimination for all scoring system.

Methods :This research enrolled 184 non-surgical patients in ICU of Sanglah Hospital restrospectively started from $1^{\text {st }}$ january to $31^{\text {st }}$ december 2014. All patient assessed by APACHE II, SOFA, and CSOFA. Analytic logistic regression test is used to determine each sub variabel correlation with mortality, and then to gain cut off point of ROC analytical curve to get sensitivity and specificity.

Result : Area under Receiver Operating Characteristic (AuROC) for APACHE, SOFA, and CSOFA is 0,892, 0,919, and 0,9172 consecutively. The missing value for SOFA, APACHE II, and CSOFA is 84,23\%, 8,15\%, dan 1,65\%, which is dominated by bilirubin parameter. Logistic regression analysis shows sub variabel neurology, cardiovascular, and respiration gave significant correlation with mortality with OR 4,58, 2,24, and 1,47. Other significant subvariable are AKI, sepsis, and chronic illness with OR 8,14, 3,89 dan 2,42.

Conclusion : CSOFA scoring system is more valid than APACHE II and SOFA to predict mortality, because it had better discrimination value and less missing value.

Keyword : Scoring system, APACHE II, SOFA, CSOFA, AuROC, missing value 


\section{ABSTRAK}

Latar Belakang : Penerapan Sistem Jaminan Kesehatan Nasional (SJKN) dalam pelayanan ICU mendorong pelayanan ICU untuk lebih efektif dan efisien. Prediksi hasil perawatan penting baik secara administrasi ataupun klinis dalam manajemen ICU. Pasien non-bedah meskipun jumlahnya tidak banyak, namun memiliki angka mortalitas yang tinggi.

Tujuan : Untuk mendapatkan sistem skoring yang baik dan mudah diterapkan dilakukan penilaian missing value, dan diskriminasi dari masing masing sistem skoring.

Metode : Penelitian ini melibatkan 184 pasien non-bedah yang dirawat di ICU RSUP Sanglah Denpasar yang diambil secara retrospektif dari data tanggal 1 Januari 2014 sampai dengan 31 Desember 2014. Semua pasien dilakukan penilaian APACHE II, SOFA, dan CSOFA. Uji analisis regresi logistik dilakukan untuk menilai pengaruh masing masing sub variabel terhadap mortalitas, dan selanjutnya mencari cut off point dari analisis kurva ROC untuk mendapatkan sensitifitas dan spesifisitas masing masing.

Hasil : Area under Receiver Operating Characteristic (AuROC) pada APACHE II, SOFA, dan CSOFA berturut turut didapatkan 0,892, 0,919, dan 0,9172. Missing value terbanyak didapatkan berturut turut pada SOFA, APACHE II, dan CSOFA sebesar $84,23 \%, 8,15 \%$, dan 1,65\%, dengan dominan sub variabel hepar (bilirubin). Uji regresi logistik memperlihatkan sub variabel neurologi, kardiovaskular, dan respirasi memberikan hubungan bermakna terhadap mortalitas dengan RO 4,58, 2,24, dan 1,47. Sub variabel lain yang berpengaruh antara lain AKI, sepsis, dan penyakit kronis dengan RO 8,14, 3,89 dan 2,42.

Simpulan : CSOFA lebih valid dalam memperkirakan mortalitas pasien di ICU RSUP Sanglah Denpasar, karena mempunyai nilai diskriminasi yang lebih baik dan missing value yang lebih sedikit dibandingkan dengan sistem skoring APACHE II dan SOFA.

Kata kunci : Sistem skoring, APACHE II, SOFA, CSOFA, AuROC, missing value

\section{PENDAHULUAN}

Praktik kedokteran saat ini berkembang dengan sangat pesat, sehingga banyak pasien dengan penyakit kritis yang dahulunya tidak dapat terselamatkan saat ini dapat bertahan hidup dengan perawatan intensif di Ruang Terapi Intensif (ICU). Namun sayangnya jumlah pasien yang meningkat tidak sejalan dengan peningkatan kapasitas perawatan di ICU sehingga diperlukan seleksi yang akurat untuk menentukan prioritas perawatan pasien di ICU. Sejalan dengan penerapan Sistem Jaminan Kesehatan Nasional melalui Badan Pelayanan Jaminan Sosial (BPJS), praktisi medis saat ini diharapkan dapat membuat perhitungan dan perkiraan 
kasar untuk prognosis dari tindakan yang akan dilakukan sehingga perkiraan biaya perawatan dapat dibuat dengan baik dan efisiensi pembiayaan dapat berjalan. Perawatan pasien kritis selalu melibatkan multi displin dengan penilaian dan cara pandang masing masing bagian, seringkali hal tersebut membingungkan dan tidak menemukan titik temu oleh karena tidak ada bahasa yang sama dalam menentukan indikator perbaikan atau keparahan penyakit. Sebagai contoh: Pasien gagal jantung kongestif tidak terkompensasi (ADHF) dengan kehamilan, di saat memberikan informed consent dari TS kandungan akan menjelaskan pasien dari bidang mereka tak ada masalah dan kandungan dalam kondisi masih stabil, kemudian TS kardiologi memberikan penjelasan kondisi jantung yang payah dan memerlukan perawatan intensif, dan terakhir dari TS tropik-infeksi yang dikonsulkan karena ada kecurigaan TBC menjelaskan bahwa paru dalam kondisi baik dari sisi tropik-infeksi. Kesimpangsiuran informasi tersebut akan membingungkan masyarakat awam karena diagnosa dan penilaian yang terkotak kotak, sehingga perlu digunakan bahasa yang sama untuk monitoring keparahan dan perbaikan kondisi pasien dengan sistem skoring yang melakukan penilaian fungsi fisiologis secara komprehensif dan holistik.

Sistem skoring yang tersedia dan lazim digunakan saat ini adalah APACHE II (Acute Physiological and Chronic Health Evaluation), namun sistem skoring ini memiliki kelemahan dari segi biaya dan kepraktisan penggunaan berkaitan dengan banyaknya variabel yang digunakan. ${ }^{1-4}$. Sistem skoring baru yang lebih praktis namun dengan akurasi yang tidak kalah baiknya dengan APACHE II perlu untuk dirumuskan.

Penelitian ini bertujuan untuk membandingkan validitas antara sistem skoring APACHE II, SOFA (Sequential Organ Failure Assessment), dan CSOFA (Customized SOFA)

\section{METODE}

Tipe penelitian ini adalah uji diagnostik dengan desain retrospektif. Penelitian telah mendapatkan ijin dari Komite Etik Penelitian Fakultas Kedokteran Universitas Udayana/RSUP Sanglah Denpasar. Pengambilan sampel dilakukan di Instalasi Rekam Medis RSUP Sanglah dengan mengambil data register pasien non-bedah yang dirawat di ICU RSUP Sanglah selama periode 1 Januari sampai dengan 31 Desember 2014 dengan pengambilan total population sample. Besar sampel minimal sesuai perhitungan Arroyo adalah 133 sampel.

Semua sampel yang didapatkan dilakukan penilaian menurut sistem skoring APACHE II, SOFA, dan 
CSOFA kemudian dikelompokkan berdasarkan luaran yaitu kelompok meninggal dan hidup. Sistem skoring SOFA (Tabel 1) dimodifikasi menjadi sistem skoring CSOFA (Tabel 2) dengan melakukan penyederhanaan pada parameter yang dinilai. Hasil tersebut kemudian dinilai validitasnya dengan uji validasi.

Uji validasi yang dilakukan adalah diskriminasi. Diskriminasi adalah kemampuan suatu penilaian dalam menentukan pasien antara yang hidup dan yang meninggal. Untuk menilai diskriminasi sistem skoring, pasien dikelompokkan berdasarkan probability of death (POD), kemudian dianalisis menggunakan tabel $2 \times 2$, untuk menghitung sensitivitas dan spesifisitasnya. Selanjutnya dibuat kurva receiver operating curve ( $\mathrm{ROC}$ curve) dengan sumbu $\mathrm{x}$ adalah nilai 1 spesifisitas (false positive rate) dan sumbu y adalah nilai sensitivitas (true positive rate). Area di bawah ROC disebut area under the ROC curve (AuROC). Nilai AuROC ini adalah nilai diskriminasi sistem skoring. Jika nilai AuROC $>0,7$, sistem penilaian tersebut mempunyai nilai diskriminasi yang baik. Semakin besar nilai AuROC suatu sistem penilaian maka semakin besar kemampuan diskriminasi sistem penilaian tersebut. Nilai $\mathrm{AuROC}=1$ menunjukkan bahwa sistem penilaian mempunyai kemampuan prediksi yang sempurna., ${ }^{5,6}$

Untuk membandingkan sistem penilaian APACHE II, SOFA dan CSOFA dalam memprediksi mortalitas, diperhitungkan missing value pada setiap sistem penilaian. Sistem penilaian dengan missing value paling kecil dianggap paling baik. Masing masing sub variabel pada sistem skoring SOFA dilakukan uji regresi logistik untuk melihat pengaruhnya terhadap luaran serta menentukan cut off point berdasarkan ROC curve.

Setiap sub variabel dari sistem skoring akan dinilai dengan analisis regresi logistik untuk melihat hubungan dengan mortalitas dengan nilai $\mathrm{P}<0,01$ dianggap bermakna

\section{HASIL}

Penelitian dilakukan pada 184 pasien yang dirawat di ICU RSUP Sanglah. (Tabel 3). Populasi pasien dibagi menjadi 2 kelompok berdasarkan luaran yaitu yang hidup dan meninggal.

Dari hasil perhitungan berdasarkan ketiga sistem skoring didapatkan rentang nilai yang luas seperti tertera pada tabel 4. Didapatkan missing value terbanyak pada SOFA score dengan dominan pada nilai bilirubin, sedangkan missing value paling kecil didapatkan pada sistem skoring CSOFA. CSOFA memperlihatkan area ROC sebesar 0,9172 .

Hubungan sub variabel skoring SOFA terhadap mortalitas pasien yang dirawat di ICU berdasarkan analisis 
Tabel 1. Sistem skoring Sequential Organ Failure Assessment (SOFA)

\begin{tabular}{|c|c|c|c|c|c|}
\hline \multirow{2}{*}{ Variabel } & \multicolumn{5}{|c|}{ Skoring SOFA } \\
\hline & 0 & 1 & 2 & 3 & 4 \\
\hline $\begin{array}{c}\text { Respirasi } \\
(\mathrm{PaO} 2 / \mathrm{FiO} 2) \mathrm{mmhg}\end{array}$ & $>400$ & $\leq 400$ & $\leq 300$ & $\leq 200$ & $\leq 100$ \\
\hline Koagulasi (platelet) & $>150$ & $\leq 150$ & $\leq 100$ & $\leq 50$ & $\leq 20$ \\
\hline Liver(bilirubin) & $<1,2$ & $1,2-1,9$ & $2,0-5,9$ & $6,0-11,9$ & $\geq 12$ \\
\hline $\begin{array}{l}\text { Kardiovaskular(hipotensi) } \\
\text { dosis dalam ug/kg/menit }\end{array}$ & $\begin{array}{l}\text { tidak ada } \\
\text { hipotensi }\end{array}$ & $\begin{array}{l}\text { MAP }<70 \\
\text { mmhg }\end{array}$ & $\begin{array}{c}\text { dopamin } \leq 5 \text { atau } \\
\text { dobutamin (dosis } \\
\text { berapapun) }\end{array}$ & $\begin{array}{c}\text { dopamin }>5 \text {, } \\
\text { adrenalin } \leq 0,1 \text {, atau } \\
\text { norepinephrine } \leq 0,1\end{array}$ & $\begin{array}{c}\text { dopamin }>15, \\
\text { adrenalin }>0,1 \text {, atau } \\
\text { norepinephrine }>0,1\end{array}$ \\
\hline $\begin{array}{c}\text { Sistem saraf pusat } \\
\text { (Glasgow Coma Scale) }\end{array}$ & 15 & $13-14$ & $12-10$ & $9-6$ & $<6$ \\
\hline $\begin{array}{l}\text { Ginjal(kreatinin serum) atau } \\
\text { jumlah urin (mL/hari) }\end{array}$ & $<1,2$ & $1,2-1,9$ & $2,0-3,4$ & $\begin{array}{c}3,5-4,9 \text { atau } \\
\text { urin }<500\end{array}$ & $>5,0$ atau urin $<200$ \\
\hline
\end{tabular}

Tabel.2 Sistem skoring Customized Sequential Organ Failure Assessment (CSOFA)

\begin{tabular}{|c|c|c|c|c|c|}
\hline \multirow{3}{*}{ Variabel } & \multicolumn{5}{|c|}{ Skoring Customized Sequential Organ Failure Assessment } \\
\hline & \multicolumn{5}{|c|}{$(C S O F A)$} \\
\hline & 0 & 1 & 2 & 3 & 4 \\
\hline Respirasi $\left(\mathrm{SpO}_{2} / \mathrm{FiO}_{2}\right)$ & $>400$ & $\leq 400$ & $\leq 315$ & $\leq 235$ & $\leq 150$ \\
\hline $\begin{array}{c}\text { GCS (Glasgow Coma } \\
\text { Scale) }\end{array}$ & 15 & $13-14$ & $10-12$ & $9-6$ & $<6$ \\
\hline $\begin{array}{c}\text { Kardiovaskular } \\
\text { (hipotensi) dosis dalam } \\
\mathrm{ug} / \mathrm{kg} / \text { menit }\end{array}$ & $\begin{array}{l}\text { Tidak ada } \\
\text { hipotensi }\end{array}$ & MAP $<70 \mathrm{mmhg}$ & $\begin{array}{c}\text { Dopamin } \leq 5 \\
\text { atau dobutamin } \\
\text { (dosis } \\
\text { berapapun) }\end{array}$ & $\begin{array}{c}\text { Dopamin }>5 \text {, } \\
\text { Adrenalin } \leq 0.1 \text {, } \\
\text { atau } \\
\text { Norepinephrine } \\
\leq 0.1\end{array}$ & $\begin{array}{c}\text { Dopamin }>15 \text {, } \\
\text { adrenalin }>0.1 \\
\text { atau } \\
\text { Norpeinephrine } \\
>0.1\end{array}$ \\
\hline Ikterik klinis & Tidak ikterik & & & Ikterik & \\
\hline Koagulasi (platelet) & $>150$ & $\leq 150$ & $\leq 100$ & $\leq 50$ & $\leq 20$ \\
\hline $\begin{array}{c}\text { Ginjal Creatinine (mg/dL) } \\
\text { atau Urine output } \\
\text { (mL/hari) }\end{array}$ & $<1,2$ & $1,2-1,9$ & $2,0-3,4$ & $\begin{array}{c}3,5-4,9 \text { atau } \\
<500\end{array}$ & $>5,0$ atau $<200$ \\
\hline
\end{tabular}


Tabel 3. Data karakteristik subyek penelitian

\begin{tabular}{ccc}
\hline \multirow{2}{*}{ Karakteristik } & \multicolumn{2}{c}{ OUTCOME } \\
\cline { 2 - 3 } & Hidup $(\mathrm{n}=67)$ & $\begin{array}{c}\text { Meninggal } \\
(\mathrm{n}=117)\end{array}$ \\
\hline Umur & & \\
Rerata(SB) & $38,9(21,6)$ & $53,9(18,9)$ \\
Median(IQR) & $31(31)$ & $56(19)$ \\
Rentang & $12-89$ & $13-89$ \\
$<65$ tahun(\%) & $57(85,1)$ & $80(68,4)$ \\
$\geq 65$ tahun(\%) & $10(14,9)$ & $37(31,6)$ \\
Jenis kelamin & & \\
Laki-laki(\%) & $36(53,0)$ & $72(61,1)$ \\
Perempuan(\%) & $31(47,0)$ & $46(38,9)$ \\
LOS & & $3(4)$ \\
Median(IQR) & $3(2)$ & $1-68$ \\
\hline Rentang & $1-42$ &
\end{tabular}

Tabel 4. Distribusi skoring, missing value, dn ROC APACHE II, SOFA, dan CSOFA

\begin{tabular}{ccccccc}
\hline $\begin{array}{c}\text { Sistem skor- } \\
\text { ing }\end{array}$ & Rerata (SB) & Rentang & Observasi & $\begin{array}{c}\text { Missing val- } \\
\text { ue }\end{array}$ & $\begin{array}{c}\text { Dominan } \\
\text { missing } \\
\text { value }\end{array}$ & $\begin{array}{c}\text { ROC } \\
\text { area }\end{array}$ \\
\hline APACHE II & $22,09(11,10)$ & $0-41$ & 169 & $15(8,15 \%)$ & AGD & 0,892 \\
SOFA & $8,62(7,10)$ & $0-19$ & 29 & $155(84,23 \%)$ & Bilirubin & 0,919 \\
CSOFA & $7,80(4,55)$ & $0-18$ & 181 & $3(1,65 \%)$ & Kreatinin & 0,9172 \\
\hline
\end{tabular}

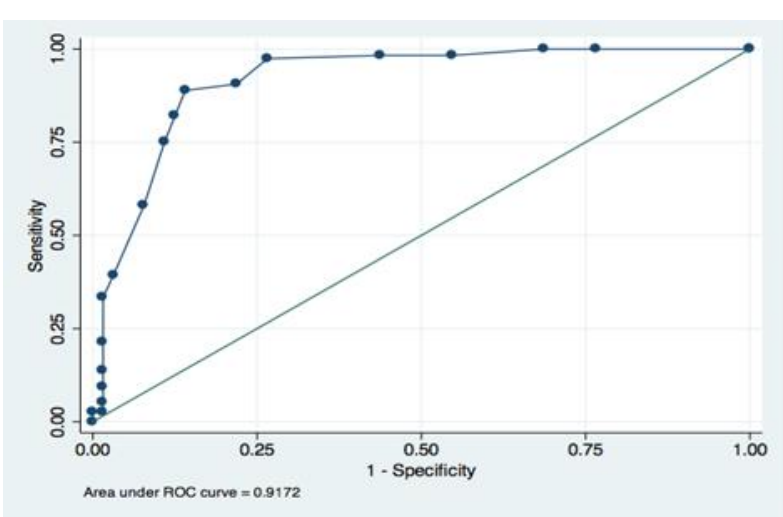

Gambar 1. Grafik area ROC skoring

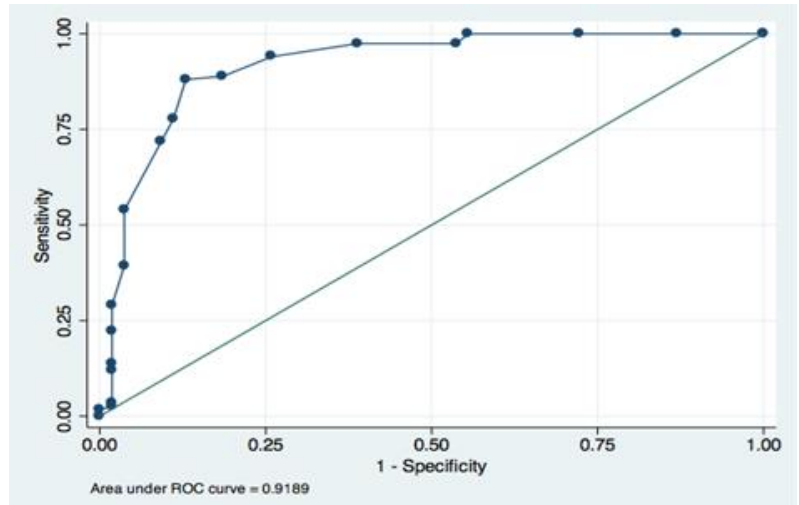

Gambar 2. Grafik area ROC skoring SOFA 


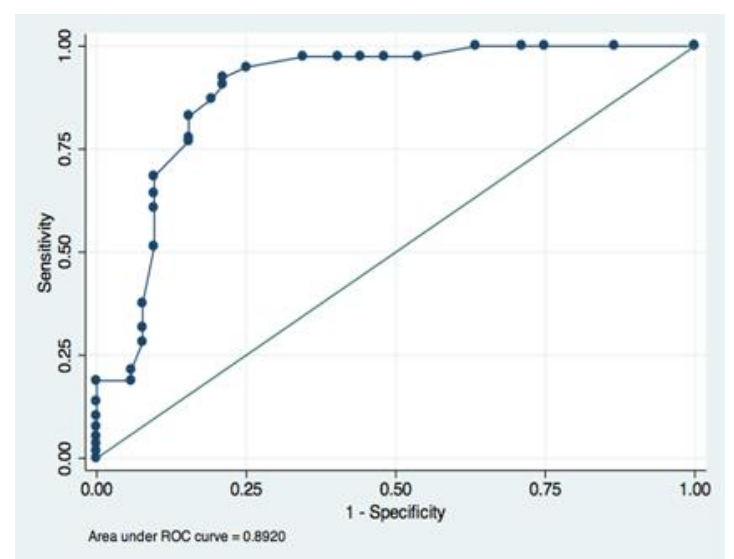

Gambar 3. Grafik area ROC skoring APACHE II

Tabel 5. Hubungan antara sub variabel skoring SOFA terhadap mortalitas berdasarkan analisis regresi logistik

\begin{tabular}{llcc}
\hline Variabel & RO & IK 95\% & P \\
\hline Respirasi & 1,79 & 1,078411 sampai 2,96215 & $0,024^{*}$ \\
Koagulasi & 0,98 & 0,5455342 sampai 1,790392 & 0,969 \\
Hepar & 2,60 & 0,3734881 sampai 17,89182 & 0,336 \\
Kardiovaskular & 2,05 & 1,17742 sampai 3,574147 & $0,011^{*}$ \\
Neurologi & 3,57 & 2,062262 sampai 6,180396 & $<0,001^{*}$ \\
Ginjal & 0,94 & 0,5771336 sampai 1,545977 & 0,821 \\
\hline
\end{tabular}

Tabel 6. Hubungan antara sub variabel AKI, penyakit kronis (APACHE II), dan sepsis terhadap mortalitas berdasarkan analisis regresi logistik

\begin{tabular}{lccc}
\hline Variabel & RO & IK 95\% & P \\
\hline AKI & 8,14 & 3,499175 sampai 18,95538 & $<0,001^{*}$ \\
Sepsis & 3,89 & 1,75845 sampai 8,595483 & $0,001^{*}$ \\
Penyakit kronis & 2,42 & 0,9492211 sampai 6,179176 & $0,064^{*}$ \\
\hline
\end{tabular}


Tabel 7. Hubungan antara sub variabel skoring CSOFA terhadap mortalitas berdasarkan analisis regresi logistik

\begin{tabular}{lccc}
\hline Variabel & RO & IK 95\% & P \\
\hline Respirasi & 1,47 & 0,9340161 sampai 2,324436 & $0,096^{*}$ \\
Koagulasi & 0,98 & 0,5747173 sampai 1,67536 & 0,945 \\
Hepar & 0,83 & 0,1220807 sampai 5,652511 & 0,85 \\
Kardiovaskular & 2,24 & 1,277078 sampai 3,959933 & $0,005^{*}$ \\
Neurologi & 4,58 & 2,611501 sampai 8,032894 & $<0.01^{*}$ \\
Ginjal & 0,85 & 0,508967 sampai 1,439147 & 0,557 \\
\hline
\end{tabular}

regresi logistik ditunjukkan pada Tabel 5. Dari keenam organ yang menjadi standar penilaian dalam skoring SOFA, hanya sub variabel respirasi $(\mathrm{P}=0,024)$, kardiovaskular $\quad(\mathrm{P}=0,011), \quad$ dan neurologi $(\mathrm{P}<0,001)$ yang berpengaruh terhadap mortalitas. Artinya, kenaikan dari sub variabel neurologi sebesar 1 unit akan meningkatkan mortalitas pasien sebesar 3,57 kali (Tabel 5). Faktor lain yang mempengaruhi mortalitas yang merupakan komponen penilaian pada APACHE II ditunjukkan pada Tabel 6 dimana didapatkan adanya AKI $(\mathrm{P}<0,001)$, dan penyakit kronis $(\mathrm{P}=0,064)$ memberikan pengaruh signifikan terhadap mortalitas demikian pula resiko mortalitas yang meningkat pada adanya kejadian sepsis $(\mathrm{P}=0,001)$. Hubungan sub variabel skoring CSOFA terhadap mortalitas pasien yang dirawat di ICU berdasarkan analisis regresi logistik ditunjukkan pada Tabel 7. Sub variabel respirasi, neurologi, dan kardiovaskular memiliki hubungan bermakna dengan mortalitas.

\section{PEMBAHASAN}

Penelitian lain mengelompokkan pasien berdasarkan divisi yang merawat. ${ }^{5-7}$ Pada penelitian ini sampel yang digunakan adalah pasien nonbedah sehingga mengelompokkan pasien dalam satu bagian akan menghilangkan bagian lain yang mungkin saja berperan, contoh: pasien dengan ADHF profile $\mathrm{C}$ dan sepsis oleh karena pneumonia, akan sulit dikelompokkan ke bagian pulmonologi, tropik-infeksi, atau jantung. Dari diagnosis yang didapatkan, dianalisis pula kejadian AKI dan sepsis memberikan hubungan yang bermakna dengan mortalitas dimana didapatkan $\mathrm{P}<0,001$ pada keduanya dan didapatkan RO 8,14 dan 3,89 pada AKI dan sepsis. Hal ini berarti setiap kejadian AKI akan meningkatkan mortalitas sampai 8,14 kali dan 3,89 kali pada kejadian sepsis. Parameter sepsis ikut dinilai sebagai luaran sekunder sebagai bagian dari evaluasi surviving sepsis campaign.

Mortality rate secara overall pada 
penelitian ini didapatkan $63,5 \%$, lebih rendah dibandingkan pada penelitian sebelumnya oleh Sunaryo, dkk. ${ }^{5}$ dimana pada pasien non pembedahan didapatkan $12(80 \%)$ dari 15 pasien meninggal. Hal ini tidak berarti perawatan ICU di RSUP Sanglah lebih baik dibandingkan perawatan ICU di tempat penelitian tersebut dilakukan meskipun rerata APACHE II dan SOFA pada penelitian ini cukup tinggi 22,09(SB 11,10) poin dengan rentang 0 -41 poin untuk APACHE II dan 8,62 (SB 7,10) poin dengan rentang 0-19 poin yang menunjukkan variasi kasus dan indeks keparahan pasien yang tinggi.

Penelitian ini menghitung missing value pada masing masing sistem skoring untuk melihat sejauh mana sistem skoring tersebut dapat diterapkan pada populasi peneliti. Pada penelitian ini didapatkan missing value terbanyak pada sistem skoring SOFA, diikuti APACHE II, dan CSOFA dengan jumlah $155(84,23 \%)$ pasien, 15 $(8,15 \%)$ pasien, dan $3(1,65 \%)$ pasien. Pada sistem skoring SOFA didapatkan jumlah missing value terbanyak pada parameter bilirubin sedangkan pada sistem skoring APACHE II dan CSOFA didapatkan missing value AGD dan kadar creatinin. Oleh karena banyaknya missing value pada penilaian SOFA sehingga hanya tersisa 29 sampel yang dapat dinilai, penulis menggunakan asumsi bilirubin yang tidak diperiksa dianggap normal dan diberi nilai 0 , hal ini sejalan dengan penelitian yang dilakukan Grissom, $\mathrm{dkk}^{8}{ }^{8}$ Dari hasil penilaian ini tampak bahwa model yang paling mudah diterapkan yang memberikan sampel yang banyak dengan parameter yang tersedia adalah CSOFA. Dari hasil analisis diskriminasi dengan menggunakan kurva ROC didapatkan secara berturut turut untuk skoring APACHE II, SOFA, dan CSOFA dengan nilai AuROC 0,892, 0,919, dan 0,917. Dari penilaian ini tampak bahwa masing masing sistem skoring cukup baik untuk diterapkan dengan nilai AuROC $>0,7$. Penilaian SOFA memiliki nilai AuROC yang tertinggi, namun di satu sisi hasil tersebut memiliki missing value yang tinggi.

Nilai AuROC adalah nilai diskriminasi sistem penilaian, semakin besar nilai AuROC suatu sistem penilaian, semakin besar pula kemampuan diskriminasi sistem penilaian tersebut. Nilai $\mathrm{AuROC}=1$ menunjukkan bahwa sistem penilaian memiliki kemampuan prediksi yang sempurna dan AuROC $=0,5$ menunjukkan bahwa persentase kesalahan dalam memprediksi adalah sama. $^{6}$

Dari kurva ROC yang didapatkan ditarik suatu titik potong (cut off point) pada masing masing sistem skoring yang menunjukkan sensitifitas dan spesifisitas yang tertinggi. Di satu sisi sensitifitas diperlukan untuk mencegah terjadinya 
under treatment, sedangkan di sisi lain spesifisitas juga diperlukan untuk menghindari over treatment yang memberi beban biaya dan waktu. Pada sistem skoring APACHE II didapatkan cut off $\geq 15$ dengan nilai overall $88,76 \%$, yang berarti pada nilai APACHE II $\geq 15$ sebaiknya perawatan dilakukan dengan berhati-hati karena resiko mortalitas akan semakin tinggi. Demikian pula pada SOFA dan CSOFA didapatkan cut off $\geq 8$ dan $\geq 5$.

Pada uji multivariat dengan regresi logistik didapatkan pengaruh pada masing masing sub variabel dari SOFA dan CSOFA dimana didapatkan komponen neurologi, respirasi dan kardiovaskular memberikan hubungan yang bermakna terhadap mortalitas. Pada sub variabel koagulasi, hepar, dan ginjal tidak memberikan hubungan yang bermakna pada mortalitas.

Sub variabel respirasi pada SOFA dan CSOFA memberikan nilai $\mathrm{P}=0,024$ dan $\mathrm{P}=0,096$ dengan $\mathrm{RO} 1,79$ dan 1,47 yang berarti setiap peningkatan 1 poin pada sub variabel respirasi akan meningkatkan angka mortalitas hingga 1,79 kali pada SOFA dan 1,47 kali pada CSOFA. Nilai RO dan P pada sistem skoring SOFA dan CSOFA yang tidak berbeda bermakna dapat diartikan keduanya memiliki interpretasi yang sama meskipun menggunakan parameter pengukuran yang berbeda yaitu $\mathrm{p} / \mathrm{f}$ ratio pada SOFA dan s/f ratio pada CSOFA. Kesimpulan ini sejalan dengan yang dilakukan oleh Pandharipande, $\mathrm{dkk}^{9}$ dan Rice, $\mathrm{dkk}^{10}$. Sub variabel kardiovaskular pada SOFA dan CSOFA memberikan nilai $\mathrm{P}=0,001$ dan $\mathrm{P}=0,005$ dengan RO 2,05 dan 2,24 yang berarti setiap peningkatan 1 poin pada sub variabel kardiovaskular akan meningkatkan angka mortalitas hingga 2,05 kali pada SOFA dan 2,24 kali pada CSOFA.

Sub variabel neurologi pada SOFA dan CSOFA memberikan nilai $\mathrm{P}<0,001$ dengan $\mathrm{RO} 3,57$ dan 4,58 yang berarti setiap peningkatan 1 poin pada sub variabel respirasi akan meningkatkan angka mortalitas hingga 3,57 kali pada SOFA dan 4,58 kali pada CSOFA. Ketiga sub variabel lainnya yaitu bilirubin (ikterik), koagulasi, dan ginjal tidak memberikan hubungan yang bermakna dimana dari hasil uji multivariat bilirubin didapatkan nilai $\mathrm{P}=0,336$ dan parameter ikterik didapatkan nilai $\mathrm{P}=0,850$. Parameter koagulasi dan ginjal berturut turut pada CSOFA memberikan nilai $\mathrm{P}=0,945$ dan $\mathrm{P}=0,557$. Dari hasil tersebut diinterpretasikan bahwa nilai sub variabel hepar, ginjal, dan koagulasi tidak memberikan hubungan yang bermakna terhadap mortalitas.

Sub variabel koagulasi pada penelitian sebelumnya yang dilakukan Sunaryo, $\mathrm{dkk}^{5}$ didapatkan tidak berhubungan terhadap mortalitas seperti halnya pada penelitian ini. Sampel dalam penelitian ini adalah pasien non-bedah, dari data yang 
diperoleh didapatkan $10(71,4 \%)$ dari 14 pasien dari kelompok hidup dengan nilai platelet $\geq 2$ adalah dengan diagnosa DHF ataupun DSS dengan nilai variabel lain cukup baik. Dari data tersebut dapat disimpulkan sensitifitas dari koagulasi sangat rendah jika dijadikan parameter penilaian, dibuktikan dengan $71,4 \%$ pasien dengan masalah pada koagulasi ternyata hidup.

Sub variabel hepar dan ginjal tidak dapat dijadikan penilaian oleh karena pada uji regresi logistik seharusnya setiap sub variabel memiliki nilai yang sejajar dan tidak saling mempengaruhi satu sama lain. ${ }^{6}$ Namun pada populasi non-bedah keterkaitan satu sama lainnya tidak dapat dihindarkan. Pada sub variabel koagulasi dengan menilai bilirubin didapatkan 3(2,56\%) dari 117 pasien yang meninggal memiliki nilai $\geq 2$, namun seluruh pasien yang masuk ke ICU dalam keadaan ikterik (4 pasien;100\%) dan tanpa gangguan hati sebelumnya (2 sepsis dan 2 ADHF) didapatkan meninggal. Bilirubin dan ikterik memiliki sensitifitas yang sangat rendah namun dengan spesifisitas yang sangat tinggi dikarenakan faktor hepar bertindak sebagai variabel antara dimana gangguan kardiovaskular akan mengakibatkan hipoperfusi pada pelbagai organ di dalam tubuh dengan organ hepar akan gagal pada urutan terakhir dikarenakan cadangannya yang sangat besar.
Pada penelitian lain yang menggunakan nilai ikterik dan mendapakan nilainya bermakna dilakukan secara serial dari hari ke hari oleh Grissom, $\mathrm{dkk}^{8}$, sedangkan desain penelitian ini hanya mengambil data awal saja, sehingga boleh jadi pada saat awal masuk fungsi hepar masih cukyp baik meskipun fungsi organ lain telah menurun.

Sub variabel ginjal dengan penelitian kreatinin serum didapatkan berhubungan bermakna dengan mortalitas pada penelitian sebelumnya. ${ }^{5,7,8,11}$ Namun penelitian tersebut menggunakan populasi nonbedah dan bedah dengan dominan populasi bedah, sebaliknya pada penelitian ini menggunakan populasi non-bedah saja. Pada populasi nonbedah didapatkan pasien dengan CKD yang telah terkompensasi dengan keadaan tersebut sehingga tidak memberi pengaruh yang signifikan. Dari data didapatkan 5(45\%) dari 11 pasien dengan nilai sub variabel ginjal $\geq 2$ yang hidup didiagnosa dengan CKD, sebaliknya 97 (82,9\%) dari 117 pasien yang meninggal memiliki nilai sub variabel ginjal $\leq 2$. Pada penilaian AKI penurunan fungsi ginjal memberikan hubungan yang bermakna terhadap mortalitas.

\section{SIMPULAN}

CSOFA lebih valid dalam memperkirakan mortalitas pasien di ICU RSUP Sanglah Denpasar, karena 
mempunyai nilai diskriminasi yang lebih baik dan missing value yang lebih sedikit dibandingkan dengan sistem skoring APACHE II dan SOFA.

\section{DAFTAR PUSTAKA}

1. Achary SP, Pradhan B, Marhatta N. Application of the SOFA score in predicting outcome in ICU patients with SIRS. Kathmandu Univ Med J. 2007;5:475-83.

2. Aftab H, Patil S, Parcells AL, Chamberlain RS. The Simplified Acute Physiology Score III is superior to the Simplified Acute Physiology Score II and Acute Physiology and Chronic Health Evaluation II in predicting surgical and ICU mortality in the oldest old. Current Gerontology and Geriatrics Research. 2014;2014:1-9.

3. Bouch DC., Thompson JP. Severity scoring systems in the critically ill. Continuing Education in Anaesth. Crit Care Pain J. 2008;8(5):181-

4. Chiavone PA, Santos Sens YA. Evaluation of APACHE II system among Intensive Care Patients at Teaching Hospital. Sao Paulo Med J. 2003;12(92):53-7.

5. Sunaryo A, Ike SR, Bisri $T$. Perbandingan validasi APACHE II dan SOFA score untuk memperkirakan mortalitas pasien yang dirawat di ruang perawatan intensif. Majalah Kedokteran terapi Intensif. 2012;2:11-20.
6. Liu H, Li G, Cumberland WG, Wu T. Testing statistical significance of the area under a receiving operating curve for repeated mesures design with bootstrapping. $\mathrm{J}$ of data science. 2005;3:257

7. Halim DA, Murni TW, Ike SR. Comparison of APACHE II, SOFA, and modified SOFA scores in predicting mortality of surgical patients in intensive care unit at Dr. Hasan Sadikin general hospital. Crit Care \& Shock. 2009;12:157-69.

8. Grissom CK, Brown SM, Kuttler KG, Boltax JP. A Modified Sequential Organ Failure Assessment (MSOFA) for critical care triage. Disaster Med Public Health Prep. 2010;4:277-84.

9. Pandharipande PP, Shintani AK, Hagerman HE, Rice TW. Derivation and validation of $\mathrm{SpO}_{2} / \mathrm{FiO}_{2}$ ratio to impute for $\mathrm{PaO}_{2} / \mathrm{FiO}_{2}$ ratio in the respiratory component of the Sequential Organ Failure Assessment score. Crit Care Med. 2009;37:1317-21.

10. Rice TW, Wheeler A.P, Bernard GR, Hayden DL. Comparison of the $\mathrm{SpO}_{2} / \mathrm{FiO}_{2}$ and the $\mathrm{PaO}_{2} / \mathrm{FiO}_{2}$ ratio in patients with acute lung injury or ARDS. Chest. 2007;132:410-7.

11. Namendy-silva SA, Medina-silva MA, Barahona VGM, Torres JA. Application of modified sequential organ failure assessment score to critically ill patients. Braz J Med Biol Res. 2013;46(2):186-93. 